DOI: $10.11649 /$ abs. 2019.010

\title{
Elena Fell
}

Tomsk Polytechnic University

Tomsk

elena.fell@ntlworld.com

https://orcid.org/0000-0002-7606-7696

\section{Izhorians: A disappearing ethnic group indigenous to the Leningrad region}

This review article presents a concise overview of selected research findings related to various issues concerning the study of Izhorians, including works by A. I. Kir'ianen, A. V. Labudin and A. A. Samodurov (Кирьянен et al., 2017); A. I. Kir'ianen, (Кирьянен, 2016); N. Kuznetsova, E. Markus and M. Muslimov (Kuznetsova, Markus, \& Muslimov, 2015); M. Muslimov (Муслимов, 2005); А. P. Chush"ialova (Чушъялова, 2010); F. I. Rozhanskiĭ and E. B. Markus (Рожанский \& Маркус, 2013); and V. I. Mirenkov (Миренков, 2000).

\section{The evolution of the term Izhorians}

The earliest confirmed record of Izhorians (also known as Ingrians), a Finno-Ugrian ethnic group native to the Leningrad region, ${ }^{1}$ appears in thirteenth-century Russian

${ }^{1}$ Whilst the city of Leningrad became the city of Saint Petersburg in 1991, reverting to its pre-Soviet name, the Leningrad region (also known as the Leningrad oblast) retained its Soviet name after the collapse of the USSR.

This is an Open Access article distributed under the terms of the Creative Commons Attribution 3.0 PL License (creativecommons.org/licenses/by/3.0/pl/), which permits redistribution, commercial and non-commercial, provided that the article is properly cited. (C) The Author(s) 2019. 
chronicles, where, according to Chistiakov (Чистяков, 2006), "Izhora” people were mentioned as early as 1228 . However, the Novgorod chronicle of 1500 , the oldest available document containing statistical data, does not specify the ethnicity of the population: in that document, people are named after the geographical location of their settlements. Consequently, Izhorians (ижоряне) are listed in the Novgorod chronicles as people who lived on the shores of the Izhora River rather than as a specific ethnic group. The term "Izhorians" became an ethnonym referring to the speakers of the Izhorian (or Ingrian) language much later, in the eighteenth century. As it is today, Izhorians are one of four Finnic ethnic groups living in Ingria, along with Votes, Estonians and Ingrian Finns. Kuznetsova, Markus and Muslimov (2015) explain the geographical location of the region as follows:

Ingria is a historical territory with the western border along the river Narva (Narova) and the lake Peipus (Chudskoe), the northern border along the Gulf of Finland and the Rajajoki (Sestra) river; the eastern border is the lake Laatokka (Ladoga) and river Lavajoki (Lava), and the southern border more or less corresponds to the southern borders of the Jaama (Kingisepp), Volossova (Volosovo), Hatsina (Gatchina) and Tusina (Tosno) districts of the Leningrad region. (Kuznetsova et al., 2015, p. 128)

\section{Dynamics of the Izhorian population: a rapid decline in the twentieth century}

Works by linguists and historians engaged in the study of Izhorians are largely concerned with uncovering the processes that underpin the deterioration and disappearance of Izhorian identity and language, and pay special attention to recording statistical data which reflect the dynamics of the Izhorian population. As can be seen in Table 1, the figures show a sharp and tragic decline of the Izhorian population in the twentieth century.

Table 1: Dynamics of the Izhorian population (Russia; the USSR; post-Soviet Russia, Estonia and Ukraine)

\begin{tabular}{|c|l|l|l|}
\hline Date & \multicolumn{1}{|c|}{ Ethnic Izhorians } & \multicolumn{1}{|c|}{$\begin{array}{c}\text { Speakers of the Izhorian } \\
\text { language }\end{array}$} & Sources and commentary \\
\hline 1732 & $\begin{array}{l}14,511 \text { Orthodox Izhorians } \\
\text { (Ingermanland) }\end{array}$ & $\begin{array}{l}\text { Presumably, all or most } \\
\text { were monolingual speakers } \\
\text { of the Izhorian language. }\end{array}$ & 1732 census (Мусаeв, 2003) \\
\hline 1848 & $\begin{array}{l}18,489 \\
\text { (including 17,800 in the St. } \\
\text { Petersburg Province and 689 } \\
\text { in Karelia) }\end{array}$ & $\begin{array}{l}\text { Presumably, all or most } \\
\text { were monolingual speakers } \\
\text { of the Izhorian language. }\end{array}$ & Köppen (1867) \\
\hline
\end{tabular}




\begin{tabular}{|c|c|c|c|}
\hline 1897 & 13,725 & $\begin{array}{l}\text { Presumably, all or most } \\
\text { were monolingual speakers } \\
\text { of the Izhorian language. }\end{array}$ & $\begin{array}{l}1897 \text { census (Ernits, 2007); } \\
\text { according to some sources (e.g. } \\
\text { Крючкова, 2003), the figure was } \\
21,700 \text {, but Ernits (2007, p. } 15) \\
\text { disagrees with this estimate }\end{array}$ \\
\hline 1917 & $\begin{array}{l}20,000 \\
\text { territory not specified }\end{array}$ & $\begin{array}{l}\text { Presumably, most were } \\
\text { monolingual speakers of } \\
\text { the Izhorian language and } \\
\text { some - Izhorian-Russian } \\
\text { bilinguals. }\end{array}$ & $\begin{array}{l}\text { Mustonen (1933); } \\
\text { Nevalainen and Hannes (1991, } \\
\text { p. } 410 \text { ) }\end{array}$ \\
\hline 1926 & 16,137 & $\begin{array}{l}\text { Presumably, most were } \\
\text { monolingual speakers of } \\
\text { the Izhorian language, with } \\
\text { the number of bilinguals } \\
\text { increasing. }\end{array}$ & $\begin{array}{l}1926 \text { census (Ernits, 2007, p. } 15 ; \\
\text { Mycaeв, 2004, p. 178); } \\
\text { Kurs (1990, p. 1487) gives the } \\
\text { number of ethnic Izhorians as } \\
26,137 \text {, but Ernits }(2007, \text { p. } 15) \\
\text { doubts that this estimate is } \\
\text { accurate }\end{array}$ \\
\hline 1942 & $\begin{array}{l}\text { Approximately } 13,000 \\
\text { (including } 8,729 \text { in the } \\
\text { occupied territory and about } \\
4,000 \text { in the Oranienbaum } \\
\text { bridgehead) }\end{array}$ & $\begin{array}{l}\text { Older generation: } \\
\text { monolingual speakers of the } \\
\text { Izhorian language; } \\
\text { younger people schooled } \\
\text { in the 1930s: bilingual } \\
\text { speakers }\end{array}$ & $\begin{array}{l}\text { Nevalainen and Hannes (1991, } \\
\text { pp. 268, 410); } \\
\text { Kurs (1990, p. 1493) }\end{array}$ \\
\hline 1959 & 1,062 & 369 & $\begin{array}{l}1959 \text { census (Ernits, 2007; La- } \\
\text { anest, 1998; Mycaeв, 2004, p. } 348 \text { ) }\end{array}$ \\
\hline 1979 & $\begin{array}{l}748 \\
\text { (total number for the USSR, } \\
\text { including } 315 \text { in the Lenin- } \\
\text { grad region) }\end{array}$ & 244 & $\begin{array}{l}1979 \text { census (Ernits, 2007, p. } 15 \text {; } \\
\text { Мусаев, } 2004 \text {, p. } 348 \text { ) }\end{array}$ \\
\hline 1989 & $\begin{array}{l}820 \\
\text { (total number for the USSR, } \\
\text { including } 276 \text { in the Lenin- } \\
\text { grad region) }\end{array}$ & 302 & $\begin{array}{l}1989 \text { census (Ernits, 2007, p. } 15 \text {; } \\
\text { Mycaeв, 2004, p. 348); } \\
\text { a larger number of Izhorians than } \\
\text { in } 1979 \text { can be explained either by } \\
\text { calculation errors or by the gradu- } \\
\text { al revival of national identity }\end{array}$ \\
\hline 2000 & $\begin{array}{l}62 \\
\text { (Estonia) }\end{array}$ & & The 2000 Census, Estonia (n.d.) \\
\hline 2001 & $\begin{array}{l}176 \\
\text { (Russian Federation) }\end{array}$ & & Kon'kova (Конькова, 2001) \\
\hline 2001 & $\begin{array}{l}812 \\
\text { (Ukraine) }\end{array}$ & & The 2001 Census, Ukraine (n.d.) \\
\hline 2013 & & $\begin{array}{l}\text { Approximately } 100 \\
\text { (Russian Federation) }\end{array}$ & $\begin{array}{l}\text { Rozhanskiǐ and Markus' } \\
\text { estimate based on field studies } \\
\text { (Рожанский \& Маркус, 2013) }\end{array}$ \\
\hline
\end{tabular}

Source: adapted from Rozhanskiŭ and Markus (Рожанский \& Маркус, 2013, p. 262) with additions and modifications by the author 


\section{The history of the Izhorian people}

It is important to remember that Izhorians, an indigenous Finno-Ugrian ethnic group populating the Leningrad region, should not be confused with Ingermanland Finns (also known as Ingrian Finns), who largely migrated to the area in the seventeenth century. What separates these ethnic groups, which speak similar languages, is religion: Izhorians are Orthodox, and Ingrian Finns are Lutheran. On the other hand, the history of Izhorians, especially in the twentieth century, cannot be considered separately from that of Ingermanland Finns, as they both suffered enormously from persecution and ethnic cleansing during the Soviet period.

The Treaty of Stolbovo, a peace treaty of 1617 that ended the seven-year Ingrian War between Sweden and Russia, was a major factor that set in motion cultural and linguistic interactions between Izhorians and Ingrian Finns. According to its provisions, "the Russian territory south of the Gulf of Finland and along both banks of the Neva River was transferred to Sweden and became known as the Swedish province of Ingermanland (Ingria)" (Кирьянен et al., 2017, p. 131, trans. EF). Finnish peasants had been slowly migrating to this area since the end of the sixteenth century, but the treaty legalised this process and encouraged further migration, mainly from areas of the modern Vyborg and Priozersk districts, the Northern Ladoga area and the south-eastern part of modern Finland (Кирьянен, 2016).

Ingria, where indigenous Izhorians and Russians now lived alongside Finnish newcomers, remained under the Swedish rule until the 1721 Russian-Swedish Treaty of Nystad confirmed new borders between Russia and Sweden as an outcome of the Great Northern War (1700-1721). ${ }^{2}$ In the years that followed, Izhorians remained one of the three ethnic groups populating Ingermanland. Musaev (Мусаев, 2003) cites the 1732 census listing 58,979 taxpaying peasants in the region in total. This number included 22,986 Lutheran Finns (who had recently migrated to the area); 14,511 Orthodox Izhorians (indigenous population); 5,883 ethnic Russians who had always lived in the region, and 10,457 "resettlers from Russian cities" (Мусаев, 2003, p. 131).

Notably, two hundred years after Ingermanland became part of the Russian Empire, the number of Lutheran Finns, according to the first All-Russian Population Census of 1897, reached 130,413, whilst the number of Izhorians decreased to 13,725 (Кирьянен et al., 2017, p. 132). It may seem strange that in the Russian

${ }^{2}$ Kir'ianen, Labudin and Samodurov (Кирьянен et al., 2017) make an important observation that the city of St Petersburg, connected with the civil and cultural identity of Izhorians and other Finnic peoples, was founded in the occupied territory, as the area it was built on was legally part of the Kingdom of Sweden in 1703. 
Empire the number of indigenous Orthodox Izhorians began to decrease, whilst the number of Ingermanland Finns, mostly Lutheran by faith, increased considerably during the same period. Kir'ianen, Labudin and Samodurov (Кирьянен et al., 2017) explain this by the fact that some Izhorians switched from Orthodox to Lutheran religion, which automatically involved adopting the Finnish language and Finnish identity. Indeed, there are Finns with Russian surnames currently living in the Leningrad region, which can serve as evidence of that transformation, indicating that the person's ancestors were Izhorians who at some point converted to the Lutheran faith and adopted the identity of Ingermanland Finns whilst retaining their original family names (Izhorians typically have Russian surnames).

There were a number of reasons for switching from Izhorian to Finnish identity. In Finnish Lutheran churches, services were conducted in Finnish, a language which Izhorians understood easily. On the other hand, they barely understood spoken Russian and did not understand at all the Church Slavonic language used in Orthodox religious ceremonies, hence it made more sense for them to attend Finnish Lutheran services (Кирьянен et al., 2017, p. 132). Moreover, in the Lutheran church, young people received confirmation when they were sixteen to eighteen years old; it was impossible to get married in a church without confirmation. In order to be confirmed, alongside religious classes they learnt to read, write and count. At the end of the course, they had to take an exam in all subjects in Finnish. In essence, young Finns received elementary education in their native language, and Kir'ianen, Labudin and Samodurov (Кирьянен et al., 2017, p. 132) further suggest that the desire to educate their children motivated many Izhorians to switch from the Orthodox to the Lutheran faith, making their children and grandchildren subsequently identify themselves as Finns. Evidently, the process of losing the Izhorian language and Izhorian identity began as early as the seventeenth century and was initially due to Izhorians assimilating with newly arrived Ingrian Finns rather than with Russians, despite living with them side by side for centuries (Кирьянен et al., 2017).

After the 1917 Russian Revolution, the relationship between the newly formed Soviet government and Izhorians, Ingemanland Finns and other Finnic minorities had a promising start. On 14 October 1920, Finland and the Russian Soviet Federated Socialist Republic (RSFSR) signed the Tartu Peace Treaty, which guaranteed Ingermanlanders' right to national and cultural autonomy, community self-determination and self-governance. In practice, this translated into the creation of 64 Finnish, Izhorian and Estonian village councils in the Leningrad region, an administrative unit established in 1927 (Кирьянен et al., 2017, pp. 132-133). Finnic languages were in official use and were taught in schools and at the Estonian, Finnish and Izhorian Pedagogical College in Leningrad. Väinö Junus, a linguist who authored the grammar of the Izhorian language (Junus, 1936), was a lecturer at the 
College promoting and developing his native language (Миренков, 2000). However, in 1934 the support for ethnic minorities began to decline rapidly. By 1937, the teaching of Finnish, Izhorian and Estonian had been banned in all schools and other educational institutions. The Pedagogical College, which functioned from 1931 (with the total number of students reaching 500), ceased to exist in 1936. The College principal M. G. Mikhelson, her deputy G. Sarkinen and other lecturers, including Väinö Junus, were executed for their alleged involvement in an anti-Soviet pro-Finnish fascist organisation and espionage (Миренков, 2000).

Prior to these events, "on 1 February 1931, the Central Executive Committee and the Council of People's Commissars of the USSR had adopted a resolution 'On granting the regional executive committees and governments of autonomous republics the right to deport kulaks from the areas of total collectivisation (sploshnaia kollektivizatsiia) of agriculture"' (TsGA SPb, f. 7179, op. 9, d. 111, 1. 83, as cited in Кирьянен et al., 2017, p. 133). To explain, the term "kulak" refers to the class of independent farmers in Russia that emerged from post-serfdom peasantry after the Stolypin agrarian reform of 1906, whereby individual peasants (householders) were allowed to privatise a portion of communal land and develop profit-oriented farming businesses. By 1915, the total number of 2,755,633 householders had applied to leave the land commune (The Stolypin agrarian reform, n.d.). The Soviets persecuted kulaks, whom they identified on the basis of the routine use of hired workers or merely owning more cattle or land than their neighbours.

Accordingly, on 15 March 1931 an $\mathrm{NKVD}^{3}$ memorandum, signed by G. G. Iagoda, the People's Commissar for Internal Affairs of the USSR, stated: "For the purpose of a complete clearing of kulaks, a mass-scale anti-kulak operation involving deportations from all regions to remote areas of the [Soviet] Union is scheduled to be conducted from May to September 1931" (Мусаев, 2003, p. 228, as cited in Кирьянен et al., 2017, p. 133). In 1930-1931 the total of 8,604 kulak families were deported from the Leningrad region to the Kola Peninsula, the Urals, Western and Eastern Siberia and Iakutia (Мусаев, 2003, p. 228), including 4,320 Finnish (and other Finnic) families, 18,000 people in total (Nevalainen, 1995, as cited in Кирьянен et al., 2017, p. 133). There is no documented evidence that Iagoda's secret instructions and the resolution adopted by the board of the regional party committee (biuro obkoma) ordered the ethnic cleansing of Finno-Ugrians. In practice, however, the entire Finnish and Estonian population of the border regions (including Izhorian families) was classified as "anti-Soviet elements" and ethnically cleansed (Кирьянен et al., 2017, p. 134).

Apart from that, on 4 October 1929 the Council of People's Commissars of the RSFSR adopted a resolution "On the resettlement of socially dangerous elements

\footnotetext{
${ }^{3}$ The People's Commissariat for Internal Affairs.
} 
of the population (sotsial'no-opasnye èlementy naseleniia) from the border areas of the Leningrad and Western regions". The resolution prescribed focusing specifically on Northern Ingermanland, on the border with Finland. Consequently, eight Finnish, seven Izhorian and three Estonian village councils were eliminated (or "liquidated", to use the Russian term), and by October 1932 about 20,000 people had been deported from the borderlands of the North-West (Иванов, 1997, p. 76, as cited in Кирьянен et al., 2017, p. 133), including the entire population of coastal settlements.

The deportations intensified: on 25 March 1935 G. G. Iagoda issued a top-secret instruction ordering the Leningrad NKVD Directorate to conduct an operation aiming "to clear the border zone of the Leningrad region and Karelia of kulaks and anti-Soviet elements" (Telegram, top-secret, GARF, f. 9479s, op. 1s, d. 28, 1. $3-5$, as cited in Кирьянен et al., 2017, p. 133). As specified, the operation was to proceed in two stages:

The first stage: in the $22 \mathrm{~km}$ border zone, the second stage: in the $100 \mathrm{~km}$ border zone and the $50 \mathrm{~km}$ border zone in Karelia. The first stage of the operation is to begin on 1 April and finish on 25 April. The proposed number of those to be deported in the first stage (3,547 families) is approved; deportations are to be carried out in the whole area at the same time. The deportees are to be transported by trains. They are strictly forbidden to leave [the area] on their own. All heads of families to be deported and able-bodied family members acting as heads of those families are to be arrested 5-7 days before the operation. Iagoda No. 55709 (after Кирьянен et al., 2017, p. 133)

This secret instruction was implemented immediately: on 28 March 1935 the head of the NKVD of the Leningrad region L. M. Zakovskil signed Order No. 0100 "On clearing the $22 \mathrm{~km}$ border zone of the kulak and anti-Soviet element". Following that, on 31 March 1935, the board of the Leningrad Regional Party Committee adopted a resolution "On clearing the border zone of the Leningrad region and the KASSR [Karelian Autonomous Soviet Socialist Republic] of the kulak and anti-Soviet element" (Мусаев, 2003, p. 258, as cited in Кирьянен et al., 2017, pp. 133-134).

Although the initial plan for April 1935 was to deport 11,795 residents of the border zone (Иванов, 2008, p. 121, as cited in Кирьянен et al., 2017, p. 134), the actual number turned out to be much higher: 5,100 families, 22,511 people (Иванов, 2008, p. 122, as cited in Кирьянен et al., 2017, p. 134). Researchers estimate that the total number of Ingermanlanders deported in 1935-1936 was approximately 26-27 thousand. Entire districts were ethnically cleansed, as Finnish families were deported during the first stage and the population of "tens of villages" (Кирьянен et al., 2017, p. 134) was removed by force. As a result of this operation, the Kuinozi Finnish National District, which stretched from Lake Ladoga to Sestroretsk (this is 
practically modern Vsevolozhsk district of the Leningrad region), was eliminated completely (Кирьянен et al., 2017, p. 134).

According to Iagoda's instructions, the second stage of deportations would have involved ethnic cleansing of the $100 \mathrm{~km}$ border strip. In the south, this territory reached the rivers Tosna, Oredezh and the upper course of the Luga River, which means that the entire territory of Ingermanland would have been cleared of the Finnish, Izhorian, Votic and Estonian population (Кирьянен et al., 2017, p. 134). However, the Soviet-Finnish War (1939-1940, known as the Winter War) and the Second World War prevented the second stage of the ethnic cleansing from being carried out.

Instead, on 24 August 1941 Stalin received a secret letter signed by V. M. Molotov, Chairman of the Council of People's Commissars and People's Commissar for Foreign Affairs of the USSR; G. M. Malenkov, Secretary of the Central Committee of the All-Union Communist Party (Bolsheviks) (VKP(B)); A. A. Zhdanov, Secretary of the Central Committee of the VKP(B) and First Secretary of the Leningrad Regional Party Committee and City Party Committee; and A. N. Kosygin, Deputy Chairman of the Council of People's Commissars of the USSR. The letter stated that a decision had been made to forcibly evacuate 88,700 Finns and 6,700 Germans from the Leningrad region to Siberia and Kazakhstan (Кирьянен et al., 2017, p. 134).

On the following day, 26 August 1941, the Military Council of the Leningrad Front adopted Resolution No. 196ss, which repeated verbatim the aforementioned secret letter (TsGA SPb, f. 7179, op. 51, d. 58, 1. 36-39, as cited in Кирьянен et al., 2017, p. 134) and ordered to carry out a forced evacuation from 27 August to 7 September 1941, with a specific instruction to arrest anyone refusing to leave (Кирьянен et al., 2017, p. 134). This order, however, was not implemented: on 8 September 1941 German troops severed the last road to Leningrad and besieged the city. Approximately 30,000 Ingrian Finns and other Finnic peoples, including Izhorians, were trapped in the besieged zone, most of them on the territory occupied by the German army (Кирьянен et al., 2017, pp. 134-135).

"In January and February 1942, the NKVD arrested several Finnish academics who worked at the Mining Institute, Technological Institutes and Leningrad University in the besieged city" (Кирьянен et al., 2017, p. 135, trans. EF). As the investigation and interrogations progressed, the NKVD presented their version of events, claiming to have discovered Ingermanland Finns' alleged plan to help Finnish troops take the city (Кирьянен et al., 2017, p. 135). Based on this claim, the Military Council of the Leningrad Front adopted Resolution No. 00714/a (20 March 1942), ordering the deportation of all ethnic Finns and Germans who were in the besieged zone at the time (TsGA SPb, f. 7179, op. 19, d. 25, 1. 25-26, as cited in Кирьянен et al., 2017, p. 135). Accordingly, a total of 58,210 of them were 
forcibly evacuated from Leningrad and the suburbs, as the chief of the NKVD for the Leningrad region reported himself on 1 October 1942 (Дзенискевич, 1995, p. 442, as cited in Кирьянен et al., 2017, p. 135).

At the same time, Ingermanlanders in north-western rural areas found themselves in the zone of German occupation (Enstad, 2018). By the winter of 1941-1942, in the occupied parts of the Leningrad region there were 76,342 speakers of Finnic languages, including 66,946 Finns, 8,729 Izhorians and 667 Votes (Nevalainen, 1992, p. 268; Мусаев, 2003, p. 294, as cited in Кирьянен et al., 2017, p. 137). Kir'ianen, Labudin and Samodurov (Кирьянен et al., 2017) write that "at the end of 1942 the German occupation administration decided to establish a fortified area on the southern shore of the Gulf of Finland and to deport the entire local population" (Кирьянен et al., 2017, p. 137, trans. EF). In the first months of 1943, special transit camps were established in Gatchina, Tosno and Volosovo districts, where all local residents were placed behind barbed wire. They were subsequently transported to the Klooga concentration camp in Estonia, where during the winter of 1943 many of them were executed or died; their piled bodies were burnt outside the camp because there was no crematorium in the camp itself (Кирьянен et al., 2017, p. 137).

While these events were unfolding, Ingermanland Finns living in Finland who had migrated there before the First World War or fled from Russia during the Civil War or in the 1920s - appealed to the Red Cross and to the Finnish government with a request to rescue their fellow Finno-Ugrians, including close relatives, from Nazi concentration camps (Nevalainen, 1990, p. 42, as cited in Кирьянен et al., 2017, p. 137). Following their appeal and the negotiations between the governments of Finland and Germany, 63,205 people were transported from occupied territories to Finland on Finnish ships (Tuuli, 1988, p. 209, as cited in Кирьянен et al., 2017, p. 137). Once quarantined, they were allocated to various farms as hired workers. Thus, during the Continuation War (1941-1944), a conflict in which Finland and Nazi Germany fought jointly against the Soviet Union, the Finnish government saved many Ingermanland Finns and Izhorians from being exterminated in Klooga (Nevalainen, 1990, p. 42, as cited in Кирьянен et al., 2017, p. 137).

The Continuation War was brought to an end by the Moscow Armistice, an agreement signed on 19 September 1944 by the USSR and the United Kingdom on one side, and Finland on the other. For the Izhorian and other Finnic evacuees this meant an inevitable return to Russia, where, as they knew, they would not be welcome: they returned from a former enemy state. Article 10 of the Armistice Agreement provided as follows:

Finland undertakes immediately to transfer to the Allied (Soviet) High Command to be returned to their homeland all Soviet and Allied prisoners of war now in her power 
and also Soviet and Allied nationals who have been interned in or deported by force to Finland. (Conditions of an Armistice with Finland, 1945, p. 262)

\section{Consequently,}

on 19 November 1944, the State Defence Committee of the USSR adopted a secret Resolution No. 6973-s, according to which 12,000 Ingrian families (approximately 50,000 people) returning from Finland instead of being allowed to come back home were to be moved to the Iaroslavl region (5,000 families), the Kalinin region (3,000), the Novgorod region $(2,000)$, the Pskov region $(1,000)$ and the Velikie Luki region $(1,000)$ (GARF, f. 327, op. 1, d. 8, 1. 1-5). (Кирьянен et al., 2017, p. 138, trans. EF)

All those returning from Finland were registered with the Ministry of Internal Affairs and were denied the right to reside in Leningrad and the Leningrad region, as well as in big cities. Only those who had received high government awards (e.g. the Medal for the Defence of Leningrad) were granted the right to go back to their homes in the region (Кирьянен et al., 2017, p. 138).

Following the end of the Second World War, on 23 September 1945 the Supreme Soviet of the USSR issued a decree "On the removal of all restrictions of wartime". However, two days before, on 21 September 1945, the Supreme Soviet had issued a secret resolution which stated that the removal of wartime restrictions did not apply to arrested or deported "troublemakers" and "anti-Soviet elements". Moreover, the resolution also stated that "anti-Soviet elements" leaving their assigned place of residence would be punished by up to twenty years of hard labour (Кирьянен et al., 2017, p. 138).

The law that required all Soviet citizens to carry a mandatory identity document, known as internal passport, was also used against Finnic people: their passports were stamped with an annotation saying "Article 38", commonly known as a "wolf ticket". This indicated a ban on residing within 101 kilometres of big cities, which made it impossible to pursue higher education. In 1954, Finns were finally allowed to return to their homes in the Leningrad region (Муллонен, 2010, as cited in Кирьянен et al., 2017, p. 139) but only to find other families living in their houses. Under the circumstances, many Izhorians moved to Estonia, which was a more favourable place for Finnic people to live owing to cultural and linguistic proximity (Рожанский \& Маркус, 2013). 


\section{Izhorian language: another victim of ethnic cleansing}

In the post-war period, Russian people who were forcibly relocated to Ingria in order to replace the deported Finno-Ugrian population displayed an openly hostile attitude towards Izhorians (as well as to other Finnic peoples). They were ridiculed and treated with contempt, and repeatedly called chukhna - a derogatory term used to refer to a Finnic person, implying that he or she is obtuse, uncivilised and backward (Рожанский \& Маркус, 2013). When Izhorians spoke in their own language, they were referred to as talapans, speakers of a nonsensical, unintelligible parlance (Рожанский \& Маркус, 2013, p. 263). The Izhorian language was suppressed in every possible way. In order to protect their children not only from ridicule and humiliation in the present, but also from persecution and deportations which they feared might happen in the future, Izhorians discouraged them from using their native language. This often came to the point that parents, whilst still communicating in Izhorian between themselves, would switch to Russian when their children entered the room (Рожанский \& Маркус, 2013).

In Russia, there had been no scholarly interest in Izhorians, their language and identity until Muslimov (Муслимов, 2005) conducted a major study of Finno-Ugric peoples of Ingermanland, in which he analysed in detail a number of sociolinguistic issues, such as self-identification, language proficiency, language attitude, language interference and code-switching. Muslimov's project focused primarily on data collected in the Lower Luga area. This study was followed by Chush"ialova's (Чушъялова, 2010) and Rozhanskiu and Markus' (Рожанский \& Маркус, 2013) research investigating Soikkola Izhorians and their dialect.

The study conducted by Rozhanskil and Markus (Рожанский \& Маркус, 2013) confirms that the Izhorian language falls into the category "nearly extinct", level $8 \mathrm{~b}$ on the Expanded Graded Intergenerational Disruption Scale (EGIDS) (Lewis \& Simons, 2010, as cited in Рожанский \& Маркус, 2013, p. 292): with rare exceptions, only a few older people speak Izhorian occasionally. Given the low status of the language and the lack of motivation for its preservation, the next stage may be level 10 "extinct" rather than level 9 "dormant". However, since there are isolated examples of middle-aged Izhorians still using the language, this transition may take decades (Рожанский \& Маркус, 2013, pp. 292-293).

Rozhanskiŭ and Markus (Рожанский \& Маркус, 2013) observe that it was not only the constant ridicule but also the fear of further persecution or deportation that irreversibly changed the language situation within a short time: Izhorian speakers refused to transfer the language to the next generation. As presented in Table 2 , they disagree on some points with Chush"ialova's analysis of the causes of the decline of the Izhorian language. Importantly, they argue that she downplays the role of Soviet persecution in the destruction of Izhorian people, and that she pre- 
sents their fate almost as if it were mostly a natural process whereby a small, weak ethnos becomes integrated into a stronger, more developed culture (Чушъялова, 2010, pp. 121-122).

Table 2: The causes of the decline of the Izhorian language: Rozhanskiĭ and Markus (Рожанский \& Маркус, 2013) reply to Chush"ialova (Чушъялова, 2010)

\begin{tabular}{|c|c|}
\hline $\begin{array}{c}\text { Chush"ialova } \\
\text { (Чушъялова, 2010) }\end{array}$ & $\begin{array}{c}\text { Rozhanskiĭ and Markus } \\
\text { (Рожанский \& Маркус, 2013) }\end{array}$ \\
\hline $\begin{array}{l}\text { During the eighteenth and nineteenth centuries, } \\
\text { Russian authorities forced Russian speakers to mi- } \\
\text { grate to and settle in the territory of Izhorians' ori- } \\
\text { ginal residence in order to assimilate the Izhorian } \\
\text { language. }\end{array}$ & $\begin{array}{l}\text { Despite the Russification of Izhora territories in } \\
\text { the eighteenth and nineteenth centuries, from the } \\
\text { mid-nineteenth century to the first quarter of the } \\
\text { twentieth century the Izhorian population (and, } \\
\text { accordingly, the number of language users) did not } \\
\text { decrease. }\end{array}$ \\
\hline $\begin{array}{l}\text { Since the 1990s, the remaining speakers of the Izho- } \\
\text { rian language (including monolingual speakers) } \\
\text { have been passing away. }\end{array}$ & $\begin{array}{l}\text { The passing away of monolinguals (which in the } \\
\text { 1990s came to an end rather than began) is a com- } \\
\text { mon process in the context of globalisation, but in } \\
\text { itself it does not lead to the extinction of a language } \\
\text { during the lifetime of one generation. }\end{array}$ \\
\hline $\begin{array}{l}\text { Infrastructure development, such as the construc- } \\
\text { tion of Ust-Luga seaport in the south-western part } \\
\text { of the Leningrad region, in the Luga Bay of the } \\
\text { Finnish Gulf, reinforces the role of the Russian lan- } \\
\text { guage as the language of technology and business } \\
\text { relations. }\end{array}$ & $\begin{array}{l}\text { The construction of the port, which intensified only } \\
\text { in recent years, could not significantly affect the lan- } \\
\text { guage situation (although, of course, it caused irre- } \\
\text { parable damage to the ecology and social structure } \\
\text { of Izhorian settlements). }\end{array}$ \\
\hline
\end{tabular}

The latest data on the state of Izhorian are provided by a research project conducted by Kuznetsova, Markus and Muslimov (Kuznetsova et al., 2015). Along with Finnish, Estonian, Karelian and Vepsian (which all belong to the Northern Finnic group of Uralic languages), they present two Izhorian (Ingrian) dialects surviving to date: the Soikkola (Soikkinskiǐ) dialect (spoken on the Soikkinskiur Peninsula, Kingisepp district) and the Lower Luga dialect (spoken in settlements alongside the lower reaches of the Luga River).

The study also accounts for the Oredezhi and Hevaha dialects of Izhorian, which are now extinct. The Oredezhi dialect (characterised by the absence of influences from Ingrian Finnish dialects and a number of unique linguistic features) was spoken on the west bank of the Ortesjoki (Oredezh) river in the Hatsina (Gatchina) district of the Leningrad region. The Hevaha dialect, in turn, was spoken in the villages along the Hevaha (Kovashi) river and along the Gulf of Finland from Uustia (Sosnovyı Bor) to Kaarosta (Oranienbaum) (Kuznetsova et al., 2015 p. 131). Kriuchkova (Крючкова, 2003, p. 167) mentions surviving Hevaha Izhorian speakers but Muslimov (Kuznetsova et al., 2015) failed to locate any competent speakers of this dialect during his field research in 2002. 
"The Soikkola dialect is spoken on the Soikkola (Soikinskií) Peninsula and along the Sista River in the Kingisepp district of the Leningrad region" (Kuznetsova et al., 2015, p. 131). There are still some surviving speakers of the Soikkola varieties, whilst Sista varieties are almost extinct. Soikkola Izhorian is slightly influenced by Soikkola Ingrian Finnish in the north and by Votic and Lower Luga Izhorian in the south (Кузнецова, 2009, as cited in Kuznetsova et al., 2015, p. 131).

"The Lower Luga dialect is [still] spoken in the villages along the lower course of the Luga River" (Kuznetsova et al., 2015, p. 131). In this case, researchers note a high level of intradialectal variation due to numerous influences from different directions: Soikkola Izhorian from the north-east, Votic from the east, Finnish from the north-west and west and Estonian from the south (Кузнецова, 2009; Муслимов, 2005, as cited in Kuznetsova et al., 2015, p. 131). Moreover, a mixed Finnish/Izhorian variety is spoken on the Kurkola (Kurgalskií) Peninsula, with its speakers originating from the villages of Hamala (Hamolovo) and Kurkula (Kurgolovo) (Kuznetsova et al., 2015, p. 131).

Kuznetsova, Markus and Muslimov (Kuznetsova et al., 2015) observe that with the ethnic identity of Izhorians and other Finno-Ugrians "shifting radically to a Russian one" (p. 133), all minority Finnic languages in Ingria, including Izhorian, are on the verge of extinction. This process, which intensified after the Second World War, has been reinforced by the increasing Russian influence on the structure of the corresponding languages (Kuznetsova et al., 2015, p. 133). The current situation makes it difficult to estimate the number of speakers of Izhorian because (1) the number of semi-speakers begins to prevail over fully competent speakers; (2) ethnic population figures differ to a great extent from the number of speakers; (3) Russian researchers cannot gain access to the many Izhorian speakers who emigrated to Estonia and Finland (Kuznetsova et al., 2015, pp. 133-134). Moreover, (4) researchers cannot rely on the speakers' evaluation of other speakers' language competence because they do not regularly communicate in Izhorian:

One can often hear estimates like "She was born in our village, so she should speak the language" (in fact, the person has forgotten almost everything), or "She speaks our language, I talk to her" (in fact, the person is able to understand and respond in simple phrases). (Kuznetsova et al., 2015, p. 134)

Kuznetsova, Markus and Muslimov (Kuznetsova et al., 2015) also established that there were people who did not communicate with their neighbours in Izhorian but remembered the language well. They also encountered situations when a person actively used Izhorian communicating with a neighbour or a relative but stopped speaking the language after their communication partner had passed away. In such cases, a competent speaker became a semi-speaker after between three to 
five years. On the other hand, the opposite process was also observed: encouraged to act as a language consultant, an Izhorian was able to revive their knowledge of the language.

Taking this complexity into consideration, Muslimov (Муслимов, 2005, p. 331, as cited in Kuznetsova et al., 2015, p. 134) developed a scale reflecting five levels of Finnic languages competence in Russia:

(1) A speaker is able to communicate in a Finnic language (including Izhorian) without code-switching;

(2) A speaker is capable of generating phrases in his or her native language, but conversations involve code-switching;

(3) A semi-speaker understands most of what is being said and can generate both single words and simple phrases in their native language;

(4) A semi-speaker understands words and simple phrases but can generate only a few of them;

(5) A person has no competence in the language at all.

In 2006, the researchers identified 54 proven speakers, 33 unproven speakers and 53 semi-speakers of the Soikkola dialect of the Izhorian language in 30 settlements of Soikkola dialectal area (Kuznetsova et al., 2015, p. 136). In the 24 settlements of the Lower Luga dialectal area, in turn, there were 57 proven speakers, 15 unproven speakers and 26 semi-speakers (Kuznetsova et al., 2015, p. 140). One particular example they mention is as follows:

In Suuri Narvusi (Bol'shoe Kuzëmkino) village, Ingrian is used by the Ingrians attending the local Lutheran church when they talk to each other or to the Finnish pastor. Ingrian speakers also talk in Ingrian to Estonian, Finnish and Russian linguists who visit their villages. Some speakers living in Estonia in winter also claimed to speak Ingrian when they meet other Ingrians in the local branches of Inkerin Liitto. ${ }^{4} \mathrm{We}$ know only one recent occasion when Ingrian was used during an official event - in 1994, a memorial plaque for the victims of Stalin's terror was unveiled in Suuri Narvusi cemetery, and a few Ingrians delivered speeches in their language. (Kuznetsova et al., 2015, p. 141)

As in 2006, 6\% of Soikkola Izhorian speakers and 22\% of the Lower Luga dialect speakers were male. Most Izhorian speakers were born in the 1930s or earlier, and the average age of a fluent speaker was above 80 . The youngest competent speaker of the Soikkola dialect was born in 1980, and her mother, who was born in 1962, spoke Izhorian fluently. The youngest known fluent speaker of Lower Luga Izhorian was born in 1935.

\footnotetext{
${ }^{4}$ Inkerin Liitto (Ingermanland Union) is the association of Finno-Ugrian people living in Russia.
} 
According to the 2002 census, there were four Izhorian people in Russia who could only speak Izhorian and did not speak Russian at all. As it is today, no Izhorian settlement has more than three proficient speakers of the language.

\section{Conclusion}

An overview of existing research on the history of Izhorians and the Izhorian language confirms that their rapid decline has been the result of persecution and ethnic cleansing, which escalated during the years before and after the Second World War. Consequently, those who survived the arrests and executions of their loved ones, deportation, violent treatment, as well as humiliation and ridicule, refused to pass the knowledge of their native language and culture to their children in order to protect future generations of Izhorians from a similar fate. As a result, the Izhorian language and identity have deteriorated. As it is today, there are under a hundred remaining speakers on the Soikkola Peninsula and in the lower reaches of the Luga River.

With only a hundred or so speakers remaining, can Izhorians and their language survive? In 2007, there was an initiative to introduce Izhorian into the school curriculum as an optional course, but eventually only lessons in local history were offered. Unfortunately, although some people wish to learn it, the lack of competent teachers is a major obstacle for its revival (Чушъялова, 2010).

One of the few functions of Izhorian in the recent years has been that of a secret language: it has been used by native speakers to communicate with one another in front of others who do not understand it. This is also the case of some other minority languages in Russia, e.g. Votic (Агранат, 2007), and amounts to an additional obstacle for their survival: some speakers consider their proficiency in these languages to be their prerogative and they do not intend to help in their restoration.

Moreover, those native speakers who are willing to share their knowledge often display a tendency to linguistic purism and, as a consequence, a negative attitude to any deviations from certain linguistic norms (Замятин, Пасанен, \& Саарикиви, 2012, pp. 35-36). However, Rozhanskii and Markus (Рожанский \& Маркус, 2013) stress that the concept of such norms is deeply individual, and that possible inconsistency of some idiolects should be attributed to dialectal differences rather than poor command of the language. Notably, some small differences in vocabulary, phonetics and grammar can be observed in neighbouring villages or even within one village. They prevent surviving speakers from accepting a common norm, which would be necessary for teaching the language (Рожанский \& Маркус, 2013, p. 194). 
Nevertheless, since there still are middle-aged people with a passive knowledge of Izhorian, there may be a possibility of its revitalisation (Рожанский \& Маркус, 2013). It may also survive in some form owing to the efforts of cultural activists, which, however, at the same time involve the risk of its "folklorisation" (Замятин et al., 2012, p. 39, as cited in Рожанский \& Маркус, 2013, p. 294), as their focus is on cultural activity (folk song and dance groups, museums, traditional crafts and so on) rather than the revitalisation of the language.

\section{Abbreviations}

GARF - State Archives of the Russian Federation (ГАРФ, Государственный архив Российской Федерации)

TsGA SPb - Saint Petersburg Central Archives (ЦГА СПб, Центральный государственный архив Санкт-Петербурга)

f. - fond (фонд) - collection

op. - opis' (опись) - inventory

d. - delo (дело) - file

1. - list (лист) - sheet

\section{Bibliography}

Conditions of an Armistice with Finland, signed at Moscow, 19th September 1944. (1945, January 7). The Department of State Bulletin, 12(289), 261-268.

Enstad, J. D. (2018). Soviet Russians under Nazi occupation: Fragile loyalties in World War II. Cambridge: Cambridge University Press. https://doi.org/10.1017/9781108367707

Ernits, E. (2007). Isurite asualadest ja algkodust. In H. Koks \& J. Rahman (Eds.), Õdagumeresoomõ kodo: Läänemeresoome kodu: Konvõrents Võrol, 19.-21. rehekuul 2006 (pp. 13-32). Võro: Võro Instituut.

Junus, V. (1936). Ižoran keelen grammatikka. Moskova: Riikin Ucebno-pedagogiceskoi Izdateljstva.

Köppen, P. (1867). Erklärender Text zu der ethnographischen Karte des St. Petersburger Gouvernements. Sankt Petersburg: Kaiserliche Akademie der Wissenschaften.

Kurs, O. (1990). Ingeri põliselanike saatus. Akadeemia. An Interdisciplinary Journal for the Humanities and Sciences, 7, 1484-1499.

Kuznetsova, N., Markus, E., \& Muslimov, M. (2015). Finnic minorities of Ingria. In H. F. Marten, M. Rießler, \& J. Saarikivi (Eds.), Cultural and linguistic minorities in 
the Russian Federation and the European Union: Comparative studies on equality and diversity (pp. 127-167). Cham: Springer. https://doi.org/10.1007/978-3-319-10455-3_6

Laanest, A. (1998). Isurid ja isuri keel. In J. Õispuu \& M. Joalaid (Eds.), Kaheksa keelt, kaheksa rahvast (pp. 30-36). Tallinn: TPÜ Kirjastus.

Lewis, M. P., \& Simons, G. F. (2010). Assessing endangerment: Expanding Fishman's GIDS. Revue roumaine de linguistique, 55(2), 103-120.

Mustonen, J. (1933). Inkerin suomalaiset (topografinen kartta 1:300000). Helsinki.

Nevalainen, P. (1990). Inkeriläinen siirtoväki Suomessa 1940-luvulla. Helsinki: Otava.

Nevalainen, P. (1992). Inkerinmaan ja inkeriläisten vaiheet 1900-luvulla. In P. Nevalainen \& H. Sihvo (Eds.), Inkeri: Historia, kansa, kulttuuri (pp. 234-299). Helsinki: Suomalaisen Kirjallisuuden Seura.

Nevalainen, P. (1995). Inkerilaiset ja Pietari: Suomi ja Pietari. Porvoo.

Nevalainen, P., \& Hannes, S. (1991). Inkeri: Historia, kansa, kulttuuri. Helsinki: Suomalaisen Kirjallisuuden Seura.

The Stolypin agrarian reform. (n.d.). Retrieved July 10, 2019, from https://community.dur. ac.uk/a.k.harrington/stolypin.html

Tuuli, E. (1988). Inkeriläisten vaellus: Inkeriläisen väestön siirto 1941-1945. Helsinki: WSOY.

The 2000 Census, Estonia. (n.d.). Retrieved July 10, 2019, from http://pub.stat.ee

The 2001 Census, Ukraine. (n.d.). Retrieved July 10, 2019, from http://www.ukrcensus. gov.ua

Агранат, Т. Б. (2007). Языковая ситуация в западной Ингерманландии в начале XXI в. (опыт полевого исследования). Вопросы филологии, 27(3), 23-30.

Гильди, Л. А. (1996). Расстрельь, ссылки, мученья. Санкт-Петербург.

Гильди, Л. А. (2003). Судьба “социально-опасного” народа: Засекреченньй геноцид финнов в России и его последствия: 1930-2002 гг. Санкт-Петербург: “ДЕАН”.

Дзенискевич, А. P. (Ed.). (1995). Ленинград в осаде: Сборник документов о герочческой обороне Ленинграда в годы Великой Отечественной войны: 1941-1944. Санкт-Петербург: Лики России.

Замятин, К., Пасанен, А., \& Саарикиви, Я. (2012). Как и зачем сохранять языки народов России? (Н. Кузнецова, Trans.). Хельсинки: Vammalan Kirjapaino Оy.

Иванов, В. А. (1997). Миссия Ордена: Механизм массовых репрессий в Советской России в конце 20-x - 40-х г2. (на материалах Северо-Запада РСФСР). Санкт-Петербург: Лисс.

Иванов, В. А. (2008). Операция “Бывшие люди” в Ленинграде (февраль - март 1935 г.) как “зачистка” прошлой России. In B. Ж. Цветков (Ed.), Исторические чтения на Лубянке: 1997-2008. Москва: Кучково поле.

Кирьянен, А. И. (2016). Коренные малочисленные народы северо-запада России и их развитие в современном правовом поле. In Сборник выступлений 
Межрегиональной научно-практической конференции “Финно-угорские народы Северо-Запада России: традиции и современность” (рр. 21-24). Санкт-Петербург.

Кирьянен, А. И., Лабудин, А. В., \& Самодуров, А. А. (2017). Ингерманландские финны: трудная история. Управленческое консультирование, 101(5), 130-141. https://doi. org/10.22394/1726-1139-2017-5-130-141

Конькова, О. (2001). Ижора. Пчела, 2001(34(July-August)).

Крючкова, Т. Б. (2003). Ижорский язык. In B. Ю. Михальченко (Ed.), Письменные языки мира: Языки Российской Федерации: Социолингвистическая энииклопедия (Vol. 2, pp. 164-173). Москва: Academia.

Кузнецова, Н. В. (2009). Супрасегментная фонология сойкинского диалекта ижорского языка в типологическом аспекте. Вопросы языкознания, 5, 18-47.

Миренков, В. И. (2000). Эстонско-финско-ижорский педагогический техникум граница трагической истории ингерманландцев. Новый часовой, 10, 363-369.

Муллонен, И. А. (2010). Адаптация ингерманландских финнов к новым условиям в Карелии во второй половине XX века. In Е. И. Клементьев (Ed.), Российские финнь: Вчера, сегодня, завтра: Сборник статей, посвященных 20-летию Ингерманландского союза финнов в Карелии. Петрозаводск: Карельский научный центр РАН. Retrieved from http://resources.krc.karelia.ru/krc/doc/publ2010/finny_2010.pdf

Мусаев, В. П. (2003). Политическая история Ингерманландии в конще XIX-XX веке. Санкт-Петербург: Нестор-История.

Мусаев, В. П. (2004). Политическая история Ингерманландии в конце ХІХ-ХХ веке (2nd ed.). Санкт-Петербург: Нестор-История.

Муслимов, М. 3. (2005). Языковые контакты в Западной Ингерманландии: Нижнее течение реки Луги (Диссертация на соискание ученой степени кандидата филологических наук). Институт лингвистических исследований Российской академии наук (ИЛИ РАН), Санкт-Петербург. Retrieved from http://www.dissercat. com/content/yazykovye-kontakty-v-zapadnoi-ingermanlandii-nizhnee-techenie-reki-lugi\#ixzz5hfWGr781

Ништадтский мирный договор между Россией и Швецией, 30 августа 1721 г. (2008). Retrieved from http://law.edu.ru/norm/norm.asp?normID=1119383

Рожанский, Ф. И., \& Маркус, Е. Б. (2013). Ижора Сойкинского полуострова: Фрагменты социолингвистического анализа. Acta Linguistica Petropolitana: Tpydы Института лингвистических исследований РАН, 9(3), 261-298. Retrieved from https://cyberleninka.ru/article/n/izhora-soykinskogo-poluostrova-fragmenty-sotsiolingvisticheskogo-analiza

Чистяков, А. Ю. (2006). Современная культура и идентичность ижоры и води: Возрождение и конструирование. Вестник Санкт-Петербургского университета. Серия 2. История, 2006(2), 152-160. Retrieved from https://cyberleninka.ru/article/n/sovremennaya-kultura-i-identichnost-izhory-i-vodi-vozrozhdenie-i-konstruirovanie-1 
Чушъялова, А. П. (2010). Исчезающие финно-угорские языки Российской Федерации на примере ижорского языка (опыт полевого исследования). Ежегодник финно-угорских исследований, 2010(3), 118-124. Retrieved from https://cyberleninka.ru/article/n/ischezayuschie-finno-ugorskie-yazyki-rossiyskoy-federatsii-na-primere-izhorskogo-yazyka-opyt-polevogo-issledovaniya

\section{Bibliography (Transliteration)}

Agranat, T. B. (2007). Iazykovaia situatsiia v zapadnoŭ Ingermanlandii v nachale XXI v. (opyt polevogo issledovaniia). Voprosy filologii, 27(3), 23-30.

Chistiakov, A. I. (2006). Sovremennaia kul'tura i identichnost' izhory i vodi: Vozrozhdenie i konstruirovanie. Vestnik Sankt-Peterburgskogo universiteta. Seriia 2. Istoriia, 2006(2), 152-160. Retrieved from https://cyberleninka.ru/article/n/sovremennaya-kultura-i-identichnost-izhory-i-vodi-vozrozhdenie-i-konstruirovanie-1

Chush"ialova, A. P. (2010). Ischezaiushchie finno-ugorskie iazyki Rossiǐskoŭ Federatsii na primere izhorskogo iazyka (opyt polevogo issledovaniia). Ezhegodnik finno-ugorskikh issledovaniŭ, 2010(3), 118-124. Retrieved from https://cyberleninka.ru/article/n/ischezayuschie-finno-ugorskie-yazyki-rossiyskoy-federatsii-na-primere-izhorskogo-yazyka-opyt-polevogo-issledovaniya

Conditions of an Armistice with Finland, signed at Moscow, 19th September 1944. (1945, January 7). The Department of State Bulletin, 12(289), 261-268.

Dzeniskevich, A. R. (Ed.). (1995). Leningrad v osade: Sbornik dokumentov o geroicheskǒ oborone Leningrada v gody Velikoŭ Otechestvennoĭ voĭny: 1941-1944. Sankt-Peterburg: Liki Rossii.

Enstad, J. D. (2018). Soviet Russians under Nazi occupation: Fragile loyalties in World War II. Cambridge: Cambridge University Press. https://doi.org/10.1017/9781108367707

Ernits, E. (2007). Isurite asualadest ja algkodust. In H. Koks \& J. Rahman (Eds.), Õdagumeresoomõ kodo: Läänemeresoome kodu: Konvõrents Võrol, 19.-21. rehekuul 2006 (pp. 13-32). Võro: Võro Instituut.

Gil'di, L. A. (1996). Rasstrely, ssylki, muchen'ia. Sankt-Peterburg.

Gil'di, L. A. (2003). Sud'ba "sotsial'no-opasnogo" naroda: Zasekrechennyı̆ genotsid finnov $v$ Rossii i ego posledstviia: 1930-2002 gg. Sankt-Peterburg: "DEAN".

Ivanov, V. A. (1997). Missiia Ordena: Mekhanizm massovykh repressiŭ v Sovetskoŭ Rossii $v$ kontse 20-kh - 40-kh gg. (na materialakh Severo-Zapada RSFSR). Sankt-Peterburg: Liss.

Ivanov, V. A. (2008). Operatsiia "Byvshie liudi” v Leningrade (fevral' - mart 1935 g.) kak "zachistka” proshloĭ Rossii. In V. Z. Tsvetkov (Ed.), Istoricheskie chteniia na Lubianke: 1997-2008. Moskva: Kuchkovo pole.

Junus, V. (1936). Ižoran keelen grammatikka. Moskova: Riikin Ucebno-pedagogiceskoi Izdateljstva. 
Kir'ianen, A. I. (2016). Korennye malochislennye narody severo-zapada Rossii i ikh razvitie v sovremennom pravovom pole. In Sbornik vystupleniŭ Mezhregional'noĭ nauchno-prakticheskoŭ konferentsii "Finno-ugorskie narody Severo-Zapada Rossii: traditsii i sovremennost'” (pp. 21-24). Sankt-Peterburg.

Kir'ianen, A. I., Labudin, A. V., \& Samodurov, A. A. (2017). Ingermanlandskie finny: trudnaia istoriia. Upravlencheskoe konsul'tirovanie, 101(5), 130-141. https://doi. org/10.22394/1726-1139-2017-5-130-141

Kon'kova, O. (2001). Izhora. Pchela, 2001(34(July-August)).

Köppen, P. (1867). Erklärender Text zu der ethnographischen Karte des St. Petersburger Gouvernements. Sankt Petersburg: Kaiserliche Akademie der Wissenschaften.

Kriuchkova, T. B. (2003). Izhorskiǔ iazyk. In V. I. Mikhal'chenko (Ed.), Pis'mennye iazyki mira: Iazyki Rossiǔskoй Federatsii: Sotsiolingvisticheskaia èntsiklopediia (Vol. 2, pp. 164-173). Moskva: Academia.

Kurs, O. (1990). Ingeri põliselanike saatus. Akadeemia. An Interdisciplinary Journal for the Humanities and Sciences, 7, 1484-1499.

Kuznetsova, N. V. (2009). Suprasegmentnaia fonologiia soǐkinskogo dialekta izhorskogo iazyka v tipologicheskom aspekte. Voprosy iazykoznaniia, 5, 18-47.

Kuznetsova, N., Markus, E., \& Muslimov, M. (2015). Finnic minorities of Ingria. In H. F. Marten, M. Rießler, \& J. Saarikivi (Eds.), Cultural and linguistic minorities in the Russian Federation and the European Union: Comparative studies on equality and diversity (pp. 127-167). Cham: Springer. https://doi.org/10.1007/978-3-319-10455-3_6

Laanest, A. (1998). Isurid ja isuri keel. In J. Õispuu \& M. Joalaid (Eds.), Kaheksa keelt, kaheksa rahvast (pp. 30-36). Tallinn: TPÜ Kirjastus.

Lewis, M. P., \& Simons, G. F. (2010). Assessing endangerment: Expanding Fishman's GIDS. Revue roumaine de linguistique, 55(2), 103-120.

Mirenkov, V. I. (2000). Ėstonsko-finsko-izhorskiı̌ pedagogicheskiĭ tekhnikum - granitsa tragicheskoĭ istorii ingermanlandtsev. Novyı̆ chasovoŭ, 10, 363-369.

Mullonen, I. A. (2010). Adaptatsiia ingermanlandskikh finnov k novym usloviiam v Karelii vo vtoroĭ polovine XX veka. In E. I. Klement'ev (Ed.), Rossiǔskie finny: Vchera, segodnia, zavtra: Sbornik state , posviashchennykh 20-letiiu Ingermanlandskogo soiuza finnov v Karelii. Petrozavodsk: Karel'skiǔ nauchnyı̆ tsentr RAN. Retrieved from http:// resources.krc.karelia.ru/krc/doc/publ2010/finny_2010.pdf

Musaev, V. P. (2003). Politicheskaia istoriia Ingermanlandii v kontse XIX-XX veke. Sankt-Peterburg: Nestor-Istoriia.

Musaev, V. P. (2004). Politicheskaia istoriia Ingermanlandii v kontse XIX-XX veke (2nd ed.). Sankt-Peterburg: Nestor-Istoriia.

Muslimov, M. Z. (2005). Iazykovye kontakty v Zapadnoŭ Ingermanlandii: Nizhnee techenie reki Lugi (Dissertatsiia na soiskanie uchenoĭ stepeni kandidata filologicheskikh nauk). Institut lingvisticheskikh issledovaniü Rossiŭskoĭ akademii nauk (ILI RAN), Sankt-Pe- 
terburg. Retrieved from http://www.dissercat.com/content/yazykovye-kontakty-v-zapadnoi-ingermanlandii-nizhnee-techenie-reki-lugi\#ixzz5hfWGr781

Mustonen, J. (1933). Inkerin suomalaiset (topografinen kartta 1:300000). Helsinki.

Nevalainen, P. (1990). Inkeriläinen siirtoväki Suomessa 1940-luvulla. Helsinki: Otava.

Nevalainen, P. (1992). Inkerinmaan ja inkeriläisten vaiheet 1900-luvulla. In P. Nevalainen \& H. Sihvo (Eds.), Inkeri: Historia, kansa, kulttuuri (pp. 234-299). Helsinki: Suomalaisen Kirjallisuuden Seura.

Nevalainen, P. (1995). Inkerilaiset ja Pietari: Suomi ja Pietari. Porvoo.

Nevalainen, P., \& Hannes, S. (1991). Inkeri: Historia, kansa, kulttuuri. Helsinki: Suomalaisen Kirjallisuuden Seura.

Nishtadtskiŭ mirnyı̌ dogovor mezhdu Rossieŭ i Shvetsieŭ, 30 avgusta 1721 g. (2008). Retrieved from http://law.edu.ru/norm/norm.asp?normID=1119383

Rozhanskiŭ, F. I., \& Markus, E. B. (2013). Izhora Soǔkinskogo poluostrova: Fragmenty sotsiolingvisticheskogo analiza. Acta Linguistica Petropolitana: Trudy Instituta lingvisticheskikh issledovaniŭ RAN, 9(3), 261-298. Retrieved from https://cyberleninka.ru/article/n/izhora-soykinskogo-poluostrova-fragmenty-sotsiolingvisticheskogo-analiza

The Stolypin agrarian reform. (n.d.). Retrieved July 10, 2019, from https://community.dur. ac.uk/a.k.harrington/stolypin.html

Tuuli, E. (1988). Inkeriläisten vaellus: Inkeriläisen väestön siirto 1941-1945. Helsinki: WSOY.

Zamiatin, K., Pasanen, A., \& Saarikivi, I. (2012). Kak i zachem sokhraniat' iazyki narodov Rossii? (N. Kuznetsova, Trans.). Khel'sinki: Vammalan Kirjapaino Oy.

The 2000 Census, Estonia. (n.d.). Retrieved July 10, 2019, from http://pub.stat.ee

The 2001 Census, Ukraine. (n.d.). Retrieved July 10, 2019, from http://www.ukrcensus. gov.ua

\title{
Izhorians: A disappearing ethnic group indigenous to the Leningrad region
}

\begin{abstract}
There is no body of research focusing specifically on Izhorians, a Finno-Ugrian minority group indigenous to the Leningrad region. Information about them is usually embedded in wider studies investigating Finnic minorities living at the intersection of Russia, Estonia and Finland. Consequently, it is fragmented, disjointed and marginalised, and available almost only in Russian, Estonian or Finnish. However, the most recent report on the state of the Izhorian language (which is part of a general study of Finnic minority languages in Russia) is available in English.
\end{abstract}


Even though information about Izhorians lacks unity and cohesion, all researchers share the same concern, namely that Izhorians are disappearing as a distinct ethnic group. This concern manifests itself as a tendency to follow the dynamics of the Izhorian population, paying special attention to statistical data. Accordingly, this paper begins with a presentation of those data as a feature that connects all available research and proceeds to a commentary clarifying the reasons for the decline of this ethnic group. It also evaluates the current state of the Izhorian language. This review article presents a concise overview of selected research findings related to various issues concerning the study of Izhorians, including works by A. I. Kir'ianen, A. V. Labudin and A. A. Samodurov (2017); A. I. Kir'ianen (2016); N. Kuznetsova, E. Markus and M. Muslimov (2015); M. Muslimov (2005); A. P. Chush"ialova (2010); F. I. Rozhanskiǐ and E. B. Markus (2013); and V. I. Mirenkov (2000).

Keywords: Izhorians; Ingrians; Ingrian Finns; Finno-Ugric peoples; Finnic minorities; Russian history; the USSR; Second World War

\section{Iżorowie - zanikająca rdzenna grupa etniczna w regionie leningradzkim}

\section{Streszczenie}

Jak dotąd, nie ma literatury badawczej skupiającej się na Iżorach, rdzennej ugrofińskiej grupie etnicznej żyjącej w regionie leningradzkim. Informacje na ich temat zwykle stanowią część szerszych prac dotyczących mniejszości bałtofińskich na pograniczu Rosji, Estonii i Finlandii, są zatem fragmentaryczne, rozproszone, zmarginalizowane i dostępne niemal wyłącznie w językach rosyjskim, estońskim lub fińskim. Najnowsze studium dotyczące stanu języka iżorskiego (stanowiące część ogólnego opracowania na temat bałtofińskich mniejszości językowych w Rosji) jest dostępne w języku angielskim. Pomimo tego, że badania dotyczące Iżorów cechuje brak spójności, wszyscy badacze podzielają obawę o ich przetrwanie jako odrębnej grupy etnicznej, co przejawia się w tendencji do śledzenia dynamiki populacji, ze szczególnym uwzględnieniem danych statystycznych. Autorka wychodzi od przedstawienia tych danych jako elementu łączącego wszystkie dostępne badania i omawia przyczyny zanikania Iżorów jako odrębnej grupy etnicznej. Artykuł przedstawia również ocenę obecnego stanu języka iżorskiego. Zawiera też zwięzły przegląd wyników wybranych badań dotyczących Iżorów i omawia prace takich autorów jak: A. I. Kir'ianen, A. V. Labudin i A. A. Samodurov (2017); A. I. Kir'ianen (2016); N. Kuznetsova, E. Markus i M. Muslimov (2015); M. Muslimov (2005); A. P. Chush"ialova (2010); F. I. Rozhanskiǐ i E. B. Markus (2013); V. I. Mirenkov (2000). 
Słowa kluczowe: Iżorowie; Ingrowie; ingryjscy Finowie; mniejszości bałtofińskie; historia Rosji; ZSRR; II wojna światowa

Dr Elena Fell is Associate Professor at the Department of Social Sciences and Humanities, Tomsk Polytechnic University, and Associate Editor of the journal Empedocles: European Journal for the Philosophy of Communication. Her research interests focus on the study of broadly conceived communication, especially crosscultural communication between Russia and the West. She has contributed to projects funded by the Arts and Humanities Research Council (UK), the Russian Foundation for Basic Research, and the Russian Scientific Fund. She has authored research publications in Russian and English.

Bibliography (selected): (with N. Lukianova and M. Shteynman), Political memes in the 2018 presidential campaigns in Russia: Dialogue and conflict, Empedocles: European Journal for the Philosophy of Communication 10/1, Bristol 2019, 71-86; Macro-reasoning and cognitive gaps: Understanding post-Soviet Russians' communication styles, ESSACHESS - Journal for Communication Studies 10, 1(19), Les Arcs 2017, 91-110; (with I. Kopsiafti), The cognitive basis of aesthetics: Cassirer, Crowther, and the future, New York 2016; (with I. Kopsiafti), Thinking space, advancing art: Cassirer and Crowther, Newcastle upon Tyne 2015; Duration, temporality, self: Prospects for the future of Bergsonism, Oxford 2012.

Correspondence: Elena Fell, Tomsk Polytechnic University, Tomsk, Russia, e-mail: elena. fell@ntlworld.com

Support of the work: This research was carried out at Tomsk Polytechnic University within the framework of the Tomsk Polytechnic University Competitiveness Enhancement Program grant.

Competing interests: The author declares that she has no competing interests. 